\title{
Investigation of gastrintestinal parasites in rabbits of the species Oryctolagus cuniculus in the Northwest region of São Paulo, Brazil
}

\author{
Investigação de parasitos gastrintestinais em coellhos da espécie Oryctolagus cuniculus na região \\ noroeste de São Paulo, Brasil \\ Investigación de parásitos gastrointestinales en conejos de la especie Oryctolagus cuniculus en la \\ región Noroeste de São Paulo, Brasil
}

Débora Regina Romualdo da Silva ORCID: https://orcid.org/0000-0001-6413-6861 São Paulo State University, Brazil E-mail: deboraregina1996@outlook.com

Sandra Valéria Inácio ORCID: https://orcid.org/0000-0001-9436-3790 São Paulo State University, Brazil E-mail: sandra_byol@yahoo.com.br

Walter Bertequini Nagata ORCID: https://orcid.org/0000-0002-5444-6695

São Paulo State University, Brazil E-mail: walter.bn@hotmail.com

Carolina Beatriz Baptista ORCID: https://orcid.org/0000-0002-2962-1842 São Paulo State University, Brazil E-mail: carolbiamv@gmail.com

Ana Paula Fernezi Bassi ORCID: https://orcid.org/0000-0002-0031-4953 São Paulo State University, Brazil E-mail: ana.bassi@unesp.br Jancarlo Ferreira Gomes ORCID: https://orcid.org/0000-0002-2466-7315 University of Campinas, Brazil E-mail: jgomes@ic.unicamp.br

Alex Akira Nakamura ORCID: https://orcid.org/0000-0002-5114-3234 São Paulo State University, Brazil E-mail: alex.nakamura@unesp.br

Katia Denise Saraiva Bresciani ORCID: https://orcid.org/0000-0002-8767-8855 São Paulo State University, Brazil E-mail: katia.bresciani@unesp.br

\begin{abstract}
Enteroparasites can be pathogenic for the rabbit population and for this reason, we have investigated its occurrence in bioterium of rabbits. The sample group was composed of 103 adult males of the species Oryctolagus cuniculus and New Zealand breed. Fecal samples $(n=103)$ were processed using the Willis Techniques (Fluctuation in saturated sodium chloride solution with specific density of $1.20 \mathrm{~g} / \mathrm{mL}$ ) and Faust (Centrifugal-flotation in zinc sulphate with density of $1.18 \mathrm{~g} / \mathrm{ml}$ ). The diameters of larger and smaller sizes of the sporocysts and sporozoites of the coccidia were measured by means of optical microscopy using the program CellSens 1.17_00_en_Rhine_13Feb2017. The Faust Technique showed positivity of 39.74\% (31/78) for Eimeria spp, while in Willis Technique, 35.90\% (28/78) was observed for Eimeria spp, being the species Eimeria perforans and in 51.28\% (47/78) of them there was no parasitism. We identified, for the first time, the occurrence of the specie E. perforans in rabbits of the species $O$. cuniculus, New Zealand breed kept in a bioterium. Therefore, it is extremely important for the implantation of parasitic control of rabbits kept in bioterium for scientific purposes, the monitoring of possible infections by means of periodic coproparasitological exams.
\end{abstract}

Keywords: Coccidiosis; Eimeria spp.; Endoparasites; Protozoan. 


\begin{abstract}
Resumo
Enteroparasitas podem ser patogênicos para a população de coelhos e por esse motivo investigamos sua ocorrência em biotérios de coelhos. O grupo amostral foi composto por 103 machos adultos da espécie Oryctolagus cuniculus e da raça Nova Zelândia. Amostras fecais $(\mathrm{n}=103$ ) foram processadas pelas Técnicas de Willis (Flutuação em solução saturada de cloreto de sódio com densidade específica de 1,20 g / mL) e Faust (Centrífuga-flotação em sulfato de zinco com densidade de $1,18 \mathrm{~g} / \mathrm{mL}$ ). Os diâmetros de tamanhos maiores e menores dos esporocistos e esporozoítos dos coccídios foram medidos por meio de microscopia óptica utilizando o programa CellSens 1.17_00_en_Rhine_13Feb2017. A Técnica de Faust apresentou positividade de 39,74\% (31/78) para Eimeria spp, enquanto na Técnica de Willis, 35,90\% (28/78) foi observado para Eimeria spp, sendo pertencente a espécie Eimeria perforans, e em 51,28\% (47/78) deles não havia parasitismo. Identificamos, pela primeira vez, a ocorrência da espécie E. perforans em coelhos da espécie $O$. cuniculus, raça Nova Zelândia mantidos em biotério. Portanto, é de extrema importância para a implantação do controle parasitário de coelhos mantidos em biotério para fins científicos, o monitoramento de possíveis infecções por meio de exames coproparasitológicos periódicos.
\end{abstract}

Palavras-chave: Coccidiose; Eimeria spp.; Endoparasitas; Protozoário.

\begin{abstract}
Resumen
Los enteroparásitos pueden ser patógenos para la población de conejos y, por esta razón, investigamos su presencia en viveros de conejos. El grupo de muestra estuvo formado por 103 machos adultos de la especie Oryctolagus cuniculus y la raza Nueva Zelanda. Las muestras fecales $(n=103)$ fueron procesadas por las Técnicas Willis (Flotación en una solución saturada de cloruro de sodio con una densidad específica de $1.20 \mathrm{~g} / \mathrm{mL}$ ) y Faust (Centrífuga-flotación en sulfato de zinc con una densidad de $1.18 \mathrm{~g}$ ) / mL). Los diámetros de tamaños más grandes y más pequeños de esporoquistes y esporozoítos de coccidia se midieron mediante microscopía óptica utilizando el programa CellSens 1.17_00_en_Rhine_13Feb2017. La Técnica de Faust mostró una positividad de 39,74\% (31/78) para Eimeria spp, mientras que la Técnica Willis mostró 35,90\% (28/78) para Eimeria spp, perteneciente a la especie Eimeria perforans, y en $51,28 \%$ (47/78) de ellos no tenía parasitismo. Identificamos, por primera vez, la ocurrencia de la especie $E$. perforans en conejos de la especie $O$. cuniculus, raza Nueva Zelanda, mantenidos en un vivero. Por tanto, es de suma importancia para la implementación del control parasitario de conejos mantenidos en vivero con fines científicos, el seguimiento de posibles infecciones mediante exámenes coproparasitológicos periódicos.
\end{abstract}

Palabras clave: Coccidiosis; Eimeria spp.; Endoparásitos; Protozoario.

\title{
1. Introduction
}

Rabbits are one of the first experimental models and have been widely used in immunological, microbiological and cardiovascular disease studies. In the literature, it is reported that the worldwide infection rate for gastrointestinal parasites in these animals is estimated at $64.00 \%$ to $100.00 \%$, which suggests that their health conditions should be of concern to researchers and may directly interfere with didactic and scientific work (Jing et al., 2016).

Intestinal parasites such as protozoa can cause serious diseases for the rabbit population (Ola-Fadunsin et al., 2019), as is the case with coccidial protozoa that cause enteric infections (Papeschi et al., 2013; Harcourt-Brown, 2014; Jing et al., 2016; Elshahawi, Elgoniemy, 2018; Maziz-Bettahar et al., 2018; Bachene et al., 2019; Ola-Fadunsin et al., 2019).

Therefore, knowledge of the prevalence of endoparasites, as well as the species that affect these animals, can contribute to the reduction of financial losses in the rabbit breeding industry, providing an estimate of the potential of the current infection and thereby enabling the implementation of control and control programs. monitoring (Elshahawi, Elgoniemy, 2018). Thus, we investigated the occurrence of gastrointestinal parasites in rabbits of the species Oryctolagus cuniculus in a bioterium.

\section{Material and Methods}

\subsection{Study population}

The sample group consisted of 103 rabbits, males and adults of the species Oryctolagus cuniculus, of the New Zealand breed, raised in the Cuniculture Sector of the Faculty of Veterinary Medicine and Animal Science - Unesp / Botucatu, São Paulo, Brazil and kept in the bioterium of the Faculty of Dentistry (FOA), Campus of Araçatuba, São Paulo, Brazil. 


\subsection{Ethics Committee}

This study was approved by the Animal Ethics and Experimentation Committee (CEEA) of FOA, Unesp, Araçatuba, SP, protocol 00197- 2020.

\subsection{Sample collection and processing}

The fecal sample was collected individually from the bottom of the cages of each of the animals involved in the study. These samples were stored, properly identified and refrigerated at $4{ }^{\circ} \mathrm{C}$ until the time of analysis.

The feces were processed using the Fluctuation Techniques in Saturated Sodium Chloride Solution with a specific density of $1.20 \mathrm{~g} / \mathrm{mL}$ (Willis, 1921), for the detection of light helminth eggs and by the Centrifuge-flotation Technique in a Saturated Solution of Zinc Sulphate with a density of $1.18 \mathrm{~g} / \mathrm{mL}$ (Faust et al., 1938), for the detection of coccidium oocysts.

The diameters of larger and smaller sizes of the sporocysts and sporozoites of Eimeria spp., Were measured by means of optical microscopy using the program cellSens 1.17_00_en_Rhine_13Feb2017, and the images were compared according to the literature (Coudert et al., 1995; Eckert et al., 1995).

\subsection{Guidance on environmental management}

A questionnaire (Figure 1) on the management and hygiene of the environment in which the rabbits were kept was applied to the person responsible for the bioterium, in the form of an interview. Based on the results of the coproparasitological exams carried out in this study, specific recommendations were formulated in relation to the environmental management to be adopted in that place.

Figure 1: Questionnaire the management and hygiene of the environment in which the rabbits.

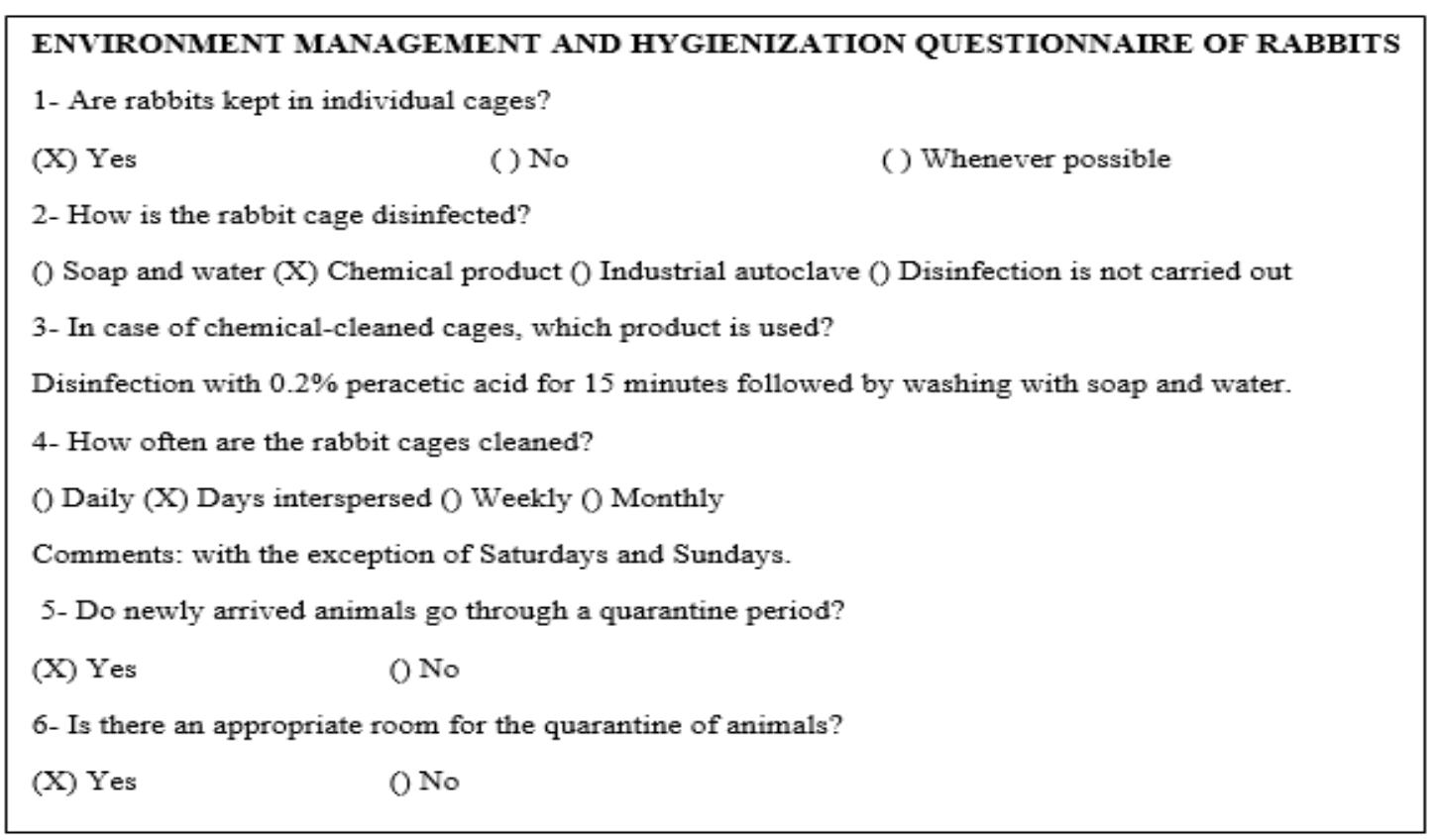

Source: Authors (2021).

\section{Results}

The occurrence of Eimeria spp. in rabbits by the Willis and Faust Technique was 35.89\% (28/78) and 39.74\% (31/78), respectively. It is important to note that according to the McNemar test, there was no significant difference between the 
proportion of positive results between the techniques used $(\mathrm{p}=0.6291)$. However, regular agreement was evidenced by the Kappa Agreement Test (0.5370), according to criteria suggested by Pereira (2001).

The measurements made in relation to the dimensions of the genus Eimeria spp. were compatible with the specie Eimeria perforans (Figure $2 \mathrm{a}, \mathrm{b}$ and c).

Figure 2: Photomicrograph of sporulated oocysts of E. perforans (A, B and C) measured from the 40x lens using the Willis technique.

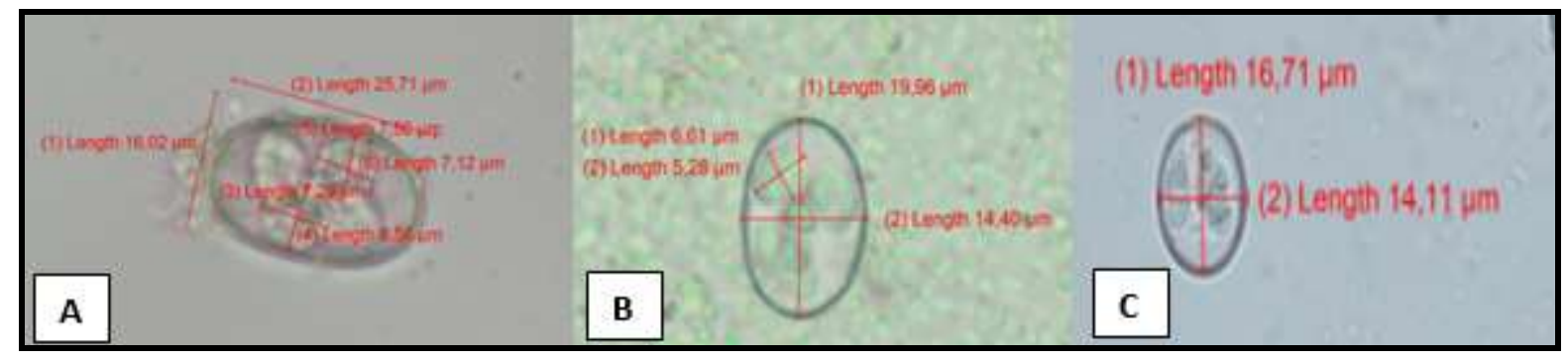

Source: Authors (2021).

According to the responses obtained in the interview with the person responsible for the bioterium, the disinfection of the cages is performed with $0.2 \%$ peracetic acid, for 15 minutes followed by washing with soap and water, on alternate days, with the exception of Saturdays and Sundays. Rabbits are kept under observation for 20 days in a separate room (quarantine). The animals are submitted to coproparasitological and hematological exams before being introduced into the vivarium, and animals with any disease are treated and kept in isolation and are reintroduced if they improve, so as not to cause bias in the research in which they are used.

\section{Discussion}

We report for the first time the occurrence of the protozoan E. perforans in rabbits of the species $O$. cuniculus, New Zealand breed kept in a bioterium. A total of 39.74\% (31/78) of fecal samples from rabbits were positive for Eimeria spp. through one of the techniques. Due to the relevance of this infection, coccidiosis is seen as a serious problem in rabbits, since the mortality rate can be high (Singla et al., 2000).

The E. perforans species, in the case of high parasitic load, develops in the crypts and villi of the duodenum, but also in the jejunum and ileum. The degree of severity of these infections seems to be related, at least partially, to the location of these coccidia. In this context, the protozoa found in rabbits act more severely, when they inhabit the crypts of the lower portion of the small intestine or cecum and the slightly or non-pathogenic species inhabit the intestinal villi (Pakandl, 2009). Therefore, the specie identified in this study is considered slightly pathogenic (Maziz-Bettahar et al., 2018).

Eleven species of Eimeria have already been identified in rabbits: E. stiedai, E. perforans, E. magna, E. media, E. irresidua, E. piriformis, E. exigua, E. flavescens, E. coecicola, E. intestinalis and E. vejdovskyi. This genus can cause digestive disorders such as anorexia, low nutritional absorption, weight reduction, dehydration, electrolyte imbalance and even the death of the infected host. Ten species inhabit the intestinal tract, with invasion and destruction of enteric cells, with the exception of E. stiedai, the only species that infects the hepatic bile ducts (Pakandl, 2009; Mäkitaipale et al., 2017; Bachene et al., 2019).

In our study, we measured the diameters of larger and smaller sizes of Eimeria spp. sporocysts and sporozoites. Thus, the identification of this coccidium was carried out based on the morphological characteristics of its oocysts and its sporulation time (Ming-Hsien et al., 2010; Elshahawi et al., 2012). Due to the great importance of species identification and the complexity of their morphological characteristics, some studies have used automated identification in the identification of gastrointestinal 
parasites (Castañón et al., 2007; Suzuki et al., 2013; Abdalla et al., 2015; Abdalla et al., 2016; Abdalla, Seker, 2017; Inácio et al., 2020).

Many parasitic diseases play a harmful role in the breeding of rabbits and result in significant economic losses, including as a result of the high mortality rate (Singla et al., 2000). A total of six rabbits died at the sample collection sites in our study. The causes of this lethality have not been thoroughly investigated, but since these animals had severe diarrhea, loss of appetite, dehydration and weight loss before death, there is a possibility of infections by Eimeria spp. have caused their death.

In other countries, in New Zealand rabbits, with different age groups, both on farms and in homes, Eimeria spp. was frequently observed, which corroborates the data of our work (Okumu et al., 2014; Jing, et al., 2016; Mäkitaipale et al., 2017; Maziz-Bettahar et al., 2018; Ola-Fadunsin et al., 2019; Gu et al., 2019).

The genus Eimeria spp. has been reported on farms in Kenya (Okumu et al., 2014) and in Algeria (Maziz-Bettahar et al., 2018) and in animals domiciled in Finland (Mäkitaipale et al., 2017) and in Nigeria (Ola-Fadunsin et al., 2019). Particularly in Brazil, it has been described in three management systems (domestic, commercial and bioterium) (Silva et al., 2006). However, in this research, sporulated samples were not used and, therefore, the species identification of this protozoan was not carried out.

In the weaning phase of rabbits, the clinical signs of coccidiosis caused by Eimeria spp. and the high production of fecal oocysts is more frequent. Since the rabbits in this study are all adults, a milder infection is expected, as has been shown previously (Mäkitaipale et al., 2017; Bachene et al., 2019).

According to the protocol for preparing animals for use in research, for rodents and rabbits in the routine of a bioterium, rabbits are kept in quarantine in an isolated room, with the purpose of monitoring the health and stabilizing the animal to the new environment (Conour et al., 2006).

Thus, based on the results of coproparasitological exams and based on the literature, we recommend the use of sanitary measures to be adopted in the routine of the vivarium in order to minimize the risks of infections in animals.

The internal environment can facilitate the transmission of Eimeria spp. among rabbits (Pakandl, 2009; Jing et al., 2012). An alternative to reduce coccidian infection is hygienic measures (Schlolaut et al., 2013). In the case of the vivarium, the disinfection of the cages is performed with $0.2 \%$ peracetic acid for 15 minutes followed by washing with water and soap, on alternate days. However, it has already been proven that this product is not very effective on sporulated oocysts, since there is a need for an exposure time of 24 hours at a concentration of 10-20\% for its inactivation (Chroustova, Pinka, 1987). A wide variety of products are marketed for chemical disinfection, many of which have been developed to eliminate bacteria or viral particles, but several of these solutions do not have ideal antiparasitic properties (Daugschies et al., 2013).

Also, vaporized hydrogen peroxide or chlorine dioxide is an effective compound to purify the environment, especially after the end of research with infectious agents (Krause et al., 2001).

Cleaning is done on alternate days with the exception of Saturdays and Sundays. In relation to the cages, where rabbits are kept, it was recommended to change the shavings daily, as well as the use of boiling water or a fire broom to inactivate the infectious evolutionary forms of the parasites. Detergents and chemical disinfectants can increase the efficiency of hot water, but the equipment must be thoroughly rinsed before being reused. The troughs must be at an adequate height so that there is no defecation inside and the cabinets and accessories (such as the top) must be cleaned daily. (Guide for the care and use of laboratory animals, 2011). It is important to clarify that it was mentioned by the person responsible for the bioterium that the rabbits had already arrived infected in the bioterium of Araçatuba and that is why they had to take closure measures for a period of 40 days, treat the sick animals, in addition to intensifying the care with these animals. In turn, the Botucatu bioterium had to end the breeding of this animal species, carry out total decontamination and start another rabbit breeding. 
In this way, an appropriate control according to the sanitary requirements is sufficient to maintain a low level of parasitic infection (Pakandl, 2009; Bachene, 2019), being of great importance, the monitoring of possible infections through periodic coproparasitological exams for the implementation of parasitic control of rabbits kept in bioterium.

\section{Conclusion}

We first identified the occurrence of E. perforans in rabbits of the species $O$. cuniculus and New Zealand breed kept in a bioterium.

\section{Formatting of funding sources}

This research did not receive any specific grant from funding agencies in the public, commercial, or not-for-profit sectors. Conflict of interest: None.

\section{References}

Abdalla, M. A. E. \& Seker, H. (2017). Recognition of Protozoan Parasites from Microscopic Images: Eimeria species in Chickens and Rabbits as a case study. Institute of Electrical and Eletronics Engineers.

Abdalla, M. A. E., Seker H. \& Jiang, R. (2015). “Automated identification of chicken Eimeria species from microscopic images,” 2015 IEEE 15th Int. Conf. Bioinforma. Bioeng. 2, 1-4.

Abdalla, M. A. E., Seker, H. \& Jiang, R (2016). “Identification of Rabbit Coccidia by Using Microscopic Images”, ICEMIS. 3-6.

Bachene, M. S., Temim, S., Ainbaziz, H. \& Bachene, A (2019). Prevalence of Rabbit Coccidia in Medea Province, Algeria. World Vet. J. 9, (2), 123-128.

Castañón, C. A. B., Fraga, J. S., Fernandez, S., Gruber, A. \& Costa, L. F. (2007). "Biological shape characterization for automatic image recognition and diagnosis of protozoan parasites of the genus Eimeria," Pattern Recognit. 40, 7, 1899-1910.

Chroustova, E. \& Pinka, K. (1987). The efficiency of disinfectants on the oocysts of Eimeria tenella, Acta vet.brno. 56, 141-149.

Conour, L. A., Murray, K. A. \& Brown, M. J. (2006). Preparation of Animals for Research-Issues to Consider for Rodents and Rabbits. ILAR Journal, 47, 4.

Coudert, P., Licois, D. \& Drouet-Viard, F. (1995). Eimeria species and strains of rabbits, In Biotechnology Guidelines on techniques in coccidiosis research. Eckert, J., Braun, R., Shirley, M. W., Coudert, P., Sc, Eds. Luxembourg: European commission. 52-73.

Daugschies, A., Bangoura, B. \& Lendner, M. (2013). Inativação de estágios de endoparasita exógenos por desinfetantes químicos: estado atual e perspectivas. Parasitol Res. 112, 917-932. 10.1007/s00436-013-3324-4.

Eckert, J., Taylor, M., Licois, D., Coudert, P., Catchpole, J. \& Bucklar, H. (1995). Identification of Eimeria and Isospora species and strains. Morphological and biological characteristics. In: Eckert J, Braun, R, Shirley, MW, Coudert, P (Ed.). Biotechnology. Guidelines on Techniques in Coccidiosis Research. Office for official publications of the European communities. Luxembourg. 103-119.

Elshahawi, G. A., El-Fayomi, H. M. \& Abdel-Haleem, H. M. (2012). Coccidiosis of domestic rabbit (Oryctolagus cuniculus) in Egypt: light microscopic study. Parasitol Res. 110:251-258.

Elshahawi, I. \& Elgoniemy, A. (2018). An Epidemiolog-ical Study on Endoparasites of Domestic Rabbits (Oryctolagus cuniculus) in Egypt with Special Refer-ence to Their Health Impact. sains Malaysiana. 47, 1, 9-18.

Faust, E. C., Sawitz, W., Tobie, J., Odom, V., Peres, C. \& Lincicome, D. R. (1939). Comparative Efficiency of Various Technics for the Diagnosis of Protozoa and Helminths in Feces. J Parasitol. 25, 3, 241-62.

Gu, X., Liu, H., Li, C., Fang, S., Cui, P., Liao, Q., Zhang, S., Wang, S., Duan, C., Yu, F., Suo, X. \& Liu, X. (2019). Selection and characterization of a precocious line of Eimeria media. Parasitology Research.

Guide for the care and use of laboratory animals (2011). Institute for Laboratory Animal Research. The national academies press 500 Fifth Street, NW Washington, Eighth Edition, DC 20001.

Harcourt-Brown, F (2014). Digestive system diseases. In: Meredith, A., Lord, B. (Eds.),BSAVA Manual of Rabbit Medicine. British Small Animal Veterinary Association, 168-190.

Inácio, S. V., Gomes, J. F., Falcão, A. X., Suzuki, C. T. N., Nagata, W. B., Loiola, S. H. N., Santos, B. M., Soares, F. A., Rosa, S. L., Baptista, C. B., Alves, G. B. \& Bresciani, K. D. S. (2020). Automated Diagnosis of Canine Gastrointestinal Parasites Using Image Analysis. Pathogens. 9, 139, 10.3390/pathogens9020139.

Jing, F., Yin, G. W., Liu, X. Y., Suo, X. \& Qin, Y. H. (2012). Large-scale survey of the prevalence of Eimeria infections in domestic rabbits in China. Parasitology Research. 110. (4), 1495-1500. 10.1007/s00436-011-2653-4. 
Research, Society and Development, v. 10, n. 10, e468101019130, 2021

(CC BY 4.0) | ISSN 2525-3409 | DOI: http://dx.doi.org/10.33448/rsd-v10i10.19130

Jing, J., Liu, C., Zhu, S. X., Jiang, Y. M., Wu, L. C., Song, H. Y. \& Shao, Y. X. (2016). Pathological and ultrastructural observations and liver function analysis of Eimeria stiedai-infected rabbits. Vet Parasitol.

Krause, J., Mcdonnell, G. \& Riedesel, H. (2001). Biodecontamination of animal rooms and heatsensitive equipment with vaporized hydrogen peroxide. Contemp Top Lab Anim Sci. 40:8-21.

Mäkitaipale, J., Karvinen, I., Virtala, A. K. \& Näreaho, A (2017). Prevalence of intestinal parasites and risk factor analysis for Eimeria infections in Finnish pet rabbits. Veterinary Parasitology: Regional Studies and Reports.

Maziz-Bettahar, S., Aissi, M., Ainbaziz, H., Bachene, M.S., Zenia, S. \& Ghisani, F. (2018). Prevalence of coccidian infection in rabbit farms in North Algeria. Veterinary World. 11, (11), 1569-1573.

Ming-Hsien, L., Hai-I, H. \& Hong-Kean, O. (2010). Prevalence, infectivity and oocyst sporulation time of rabbit-coccidia in Taiwan. Trop Biomed. 27, 424429.

Okumu, P. O., Gathumbi, P., Karanja, D. N., Mande, J. D., Wanyoike, M. M., Gachuiri, C. K., Kiarie, N., Mwanza R. N. \& Borter, R. N. (2014). Prevalence, pathology and risk factors for coccidiosis in domestic rabbits (Oryctolagus cuniculus) in selected regions in Kenya, Veterinary Quarterly. 34, (4), 205-210.

Ola-Fadunsin, S. D., Nuhu, A. A., Fabiyi, J. P., Sanda, I. M., Hussain, K., Rabiu, M. \& Ganiyu, I. A. (2019). Prevalence and associated risk factors of Eimeria species in rabbits (Oryctolagus cuniculus) in Ilorin, Kwara State, Nigeria. Annals of Parasitology. 65 (3), 267-273.

Pakandl, M. (2009). Coccidia of rabbit: A review. Folia Parasitol. 56, 153-166. 10.14411/fp.2009.019.

Papeschi, C., Fichi, G. \& Perrucci, S. (2013). Oocyst excretion pattern of three intestinal Eimeria species in female rabbits. World Rabbit Science. 21, (2), 7783. $10.4995 /$ wrs. 2013.1235 .

Pereira, M. G. (2001). Epidemiology theory and practice. Guanabara Koogan. 596.

Ruddy, M. \& Kibbler, C. C. (2002). Endoscopic decontamination: an audit and practical review. J Hosp Infect. 50, 261-268.

Schlolaut, W., Hudson, R. \& Rödel, H. G. (2013). Impact of rearing management on health in domestic rabbits: A review. World Rabbit Science. 21, (3), 145159. 10.4995/wrs.2013.1029.

Shek, W. R. \& Gaertner, D. J. (2002). Controle de qualidade microbiológica para roedores de laboratório e lagomorfos, 365-393. In: Fox, J. G., Anderson, L. C., Loew, F. M., \& Quimby, F. W. Medicina animal de laboratório. Academic Press.

Silva, A. S., Ceolin, L. \& Monteiro, S. G. (2006). Rabbit endoparasitoses reared in different management systems. Jornal FZVA, Uruguaiana. 13, 2, 127-136.

Singla, L. D., Juyal, P. D. \& Andhu, B. S. (2000). Patologia e terapia em coelhos naturalmente infectados por Eimeria stiedae. J. Protozool. Res. 10, 185 191.

Suzuki, C. T. N., Gomes, J. F., Falcao, A. X., Papa, J. P. \& Hoshino-Shimizu, S. (2013). "Automatic segmentation and classification of human intestinal parasites from microscopy images," IEEE Trans. Biomed. Eng. 60, 3, 803-812.

Willis, H. H. A (1921). Simple Levitation Method for the Detection of Hookworm Ova. Med J Aust <https://www.cabdirect.org/cabdirect/abstract/19222900461>. 